\title{
Pengaruh Return On Equity, Current Ratio Dan Debt To Asset Ratio Terhadap Financial Distress (Pada Perusahaan Sektor Agriculture yang Terdaftar di Bursa Efek Indonesia Tahun 2016-2019)
}

\author{
Miranda Putri ${ }^{1}$, Mohamad Zulman Hakim ${ }^{2}$, Dirvi Surya Abbas ${ }^{3}$ \\ Universitas Muhammadiyah Tangerang ${ }^{1,2,3}$ \\ Koresponden Email: miraputri85@gmail.com
}

\begin{abstract}
Abstrak: Peneilitian ini bertujuan untuk mengetahui pengaruh Return on Equity, Current Ratio dan Debt to Asset Ratio terhadap kondisi Financial Distress. Pendekatan yang digunakan dalam penelitian ini adalah metode penelitian secara kuantitatif. Populasi penelitian ini adalah perusahaan agrikultur yang terdaftar di Bursa Efek Indonesia pada tahun 2016-2019. Pengambilan sampel dalam penelitian ini menggunakan metode purposive sampling diperoleh 32 sampel dengan jumlah 8 perusahaan. Penelitian ini menggunakan metode analisis regresi linier berganda dengan bantuan program EViews 9.0. Hasil penelitian ini adalah Return on Equity dan Current Ratio tidak memiliki pengaruh terhadap Financial Distress. Sedangkan Debt to Asset Ratio memiliki pengaruh negatif terhadap Financial Distress.
\end{abstract}

Kata Kunci : ROE, CR, DAR dan Financial Distress.

Financial distress adalah kondisi keuangan suatu perusahaan yang mengalami kesulitan dan menurun dari tahun ke tahun, keadaan ini jika terus-menerus tidak diatasi dengan baik maka dapat menyebabkan terjadinya kebangkrutan. Keadaan ekonomi dunia yang memburuk memberikan peringatan pada perusahaan agar lebih berhati-hati terhadap dampak pada kinerja perusahaan. Langkah yang harus dilakukan perusahaan yaitu dengan memperkuat fundamental perusahaan. Jika manajemen perusahaan tidak dapat mengelola keuangan dengan baik maka perlahan perusahaan akan mengalami financial distress.

Sektor pertanian merupakan sektor yang berpengaruh dan memiliki kontribusi yang besar terhadap perekonomian Indonesia, karena Indonesia adalah negara agraris dan memiliki sumberdaya yang melimpah. Kemampuan yang dimiliki sektor pertanian Indonesia sangat luar biasa seperti kelapa sawit, karet dan coklat produksi Indonesia mulai menguasai pasar dunia. (Adharsyah, 2019)

Untuk memprediksi kondisi financial distress dapat menggunakan Rasio profitabilitas. Return On Equity (ROE) merupakan bagian dari analisis rasio profitabilitas. Menurut (Margaretha, 2014) return on equity merupakan cara untuk mengukur tingkat pengembalian atas investasi bagi pemegang saham biasa. Rasio likuiditas dapat digunakan untuk memprediksi terjadinya financial distress. Rasio likuiditas yang dapat digunakan dalam penelitian terhadap fiancial distress adalah rasio lancar (current ratio). Current Ratio menurut (Abidin, 2014) rasio ini yang juga disebut sebagai rasio cepat merupakan rasio yang membandingkan 
antara aktiva lancar dengan utang lancar. Rasio leverage juga dapat digunakan sebagai indikator untuk memprediksi terjadinya financial distress. Debt to Asset Ratio adalah salah satu bagian dari rasio leverage. yaitu rasio yang membandingkan jumlah utang terhadap aset. Rasio ini sangat penting bagi kreditur karena dapat mengukur seberapa tinggi risiko utang yang diberikan kepada debitur.

Teori Sinyal (Signaling Theory) yaitu eksekutif perusahaan yang mempunyai informasi yang baik dan memberikan informasi tersebut kepada investor, informasi yang baik itu berupa prospek di masa mendatang yang diharapkan dapat meningkatkan harga saham perusahaan. Kondisi financial distress merupakan sebuah sinyal untuk para investor agar para investor tidak akan salah untuk menanamkan modalnya tersebut.

Menurut (Wijarnarto \& Nurhidayat, 2016) Profitabilitas (ROE) berpengaruh negatif dan signifikan terhadap Financial Distress. Sedangkan menurut (Erayanti, 2019) Hasil pengujian hipotesis atas pengaruh variabel profitabilitas (Return On Equity) terhadap financial distress menunjukkan bahwa tidak adanya pengaruh variabel profitabilitas secara signifikan terhadap financial distress. Menurut (Ginting, 2017) Variabel Likuiditas (current ratio) mempunyai pengaruh signifikan yang positif terhadap financial distress. Sedangkan menurut (Curry, Banjarnahor, Diploma, \& Keuangan, 2018) Likuiditas dengan menggunakan pengukuran current ratio dapat menunjukkan pengaruh negatif likuiditas terhadap financial distress. Kemudian menurut (Srikalimah, 2017) Likuiditas (CR) tidak mempunyai pengaruh yang signifikan dalam memprediksi financial distress. Menurut (Moleong, 2018) Variabel tingkat leverage (DAR) memiliki pengaruh positif terhadap financial distress. Sedangkan menurut (Curry et al., 2018) Leverage $(D A R)$ tidak mempunyai pengaruh yang signifikan dalam memprediksi financial distress.

Adapun tujuan penelitian ini yaitu untuk membuktikan secara empiris pengaruh Return on Equity, Current Ratio dan Debt to Asset Ratio terhadap Financial Distress perusahaan sektor agriculture pada periode 2016-2019.

\section{METODE}

\section{A. Pendekatan Penelitian}

Pendekatan yang digunakan dalam penelitian ini adalah metode penelitian secara kuantitatif yaitu suatu pendekatan yang menggunakan model matematika, model statistik dan model ekonometrik yang hasilnya dapat disajikan dalam bentuk angka-angka yang kemudian dijelaskan dan juga diintrepretasikan dalam suatu uraian. Teknik analisis data dalam penelitian ini yaitu menggunakan pendekatan penelitian asosiatif yang didasarkan pada data sekunder berupa laporan keuangan pada perusahaan agrikultur yang terdaftar di Bursa Efek Indonesia (BEI) pada tahun 2016-2019. 


\section{B. Metode Pengambilan Sampel}

Pengambilan sampel dalam penelitian ini menggunakan metode purposive sampling. Menurut (Sugiyono, 2011), metode purposive sampling adalah teknik penentuan sampel berdasarkan kriteria atau pertimbangan tertentu. Kriteria-kriteria yang digunakan adalah sebagai berikut:

1. Perusahaan agrikultur yang terdaftar di Bursa Efek Indonesia periode 2016-2019.

2. Perusahaan agrikultur yang mempublikasikan laporan keuangan dan laporan tahunan berturut-turut di Bursa Efek Indonesia periode 20162019.

3. Perusahaan agrikultur yang menggunakan mata uang Rupiah dalam laporan keuangan dan tahunannya.

4. Perusahaan agrikultur yang mengalami financial distress periode 2016-2019.

C. Metode Analisis Data

2. Analisis Statistik Deskriptif

Menurut (Syaputri, 2019) menjelaskan bahwa analisis deskriptif menggambarkan tentang ringkasan data-data penelitian seperti mean, standar deviasi, variasi, modus, dan sebagainya.

3. Estimasi Regresi Data Panel

a. Common Effects Model

Teknik ini merupakan teknik yang paling sederhana untuk mengestimasi parameter model data panel, yaitu dengan mengkombinasikan data cross section dan time series sebagai satu kesatuan tanpa melihat adanya perbedaan waktu dan entitas (individu). Dimana pendekatan yang sering dipakai adalah metode Ordinary Least Square (OLS). Model Common Effect mengabaikan adanya perbedaan dimensi individu maupun waktu atau dengan kata lain perilaku data antar individu sama dalam berbagai kurun waktu, (Widarjono, 2007).

b. Fixed Effects Model

Pendekatan model Fixed Effect mengasumsikan bahwa intersep dari setiap individu adalah berbeda sedangkan slope antar individu adalah tetap (sama). Teknik ini menggunakan variabel dummy untuk menangkap adanya perbedaan intersep antar individu, (Widarjono, 2007).

c. Random Effects Model

Pendekatan yang dipakai dalam Random Effect mengasumsikan setiap perusahaan mempunyai perbedaan intersep, yang mana intersep tersebut adalah variabel random atau stokastik. Model ini sangat berguna jika individu (entitas) yang diambil sebagai sampel adalah dipilih secara random dan merupakan wakil populasi. Teknik ini juga memperhitungkan bahwa error mungkin berkorelasi sepanjang cross section dan time series, (Widarjono, 2007). 
4. Teknik Pemilihan Regresi Data Panel

a. Uji Chow

(Eksandy, 2018)

5. Uji Hipotesis

a. Uji F

Uji ini digunakan untuk menjelaskan apakah semua variabel bebas secara bersama-sama memiliki pengaruh terhadap variabel terikat. Hipotesis dalam uji $\mathrm{F}$ adalah sebagai berikut:

1) Berdasarkan perbandingan antara $F$-statistik dengan $F$ tabel $\mathrm{HO}$ : nilai F-statistik < F Tabel

$\mathrm{Ha}$ : nilai F-statistik > F Tabel

1) Berdasarkan probabilitas

$\mathrm{HO}$ : nilai Prob (F-statistic) > a $(0,05)$

b. Uji t

$\mathrm{Ha}:$ nilai Prob (F-statistic) $<\mathrm{a}(0,05)$

Uji ini digunakan untuk menjelaskan apakah signifikan pengaruh variabel bebas terhadap variabel terikat. Hipotesis dalam uji $\mathrm{t}$ adalah sebagai berikut:

1) Berdasarkan perbandingan antara t statistic dengan t tabel:

$\mathrm{HO}$ : nilai t-statistic $<\mathrm{t}$ table

$\mathrm{Ha}$ : nilai t-statistik $>\mathrm{t}$ table

2)Berdasarkan probability

$\mathrm{HO}$ : nilai Prob. $>$ a $(0,05)$

$\mathrm{Ha}$ : nilai Prob. < a $(0,05)$

c. Koefisien Determinasi

Koefisien Determinasi digunakan untuk menjelaskan seberapa besar kontribusi pengaruh variabel bebas terhadap variabel terikat. Nilai R-squared berada antara 0 sampai 1 dengan penjelasan sebagai berikut:

1) Nilai R-squared harus berkisar 0 sampai 1

2) Jika nilai R-squared sama dengan 1, berarti naik atau turunnya variabel terikat $100 \%$ dipengaruhi oleh variabel bebas.

Jika nilai R-squared sama dengan 0 , berarti tidak ada hubungan sama sekali antara variabel bebas terhadap variabel terikat.

6. Analisis Regresi Data Panel

Analisis Regresi Data Panel adalah data dari beberapa perusahaan yang diamati dalam bebrapa kurun waktu tertentu. Berikut persamaan regresi data panel:

$$
Y_{i t}=\beta_{0}+\beta_{1} X_{1 i t}+\beta_{2} X_{2 i t}+\beta_{3} X_{2 i t}+\varepsilon_{i t}
$$

Keterangan:

Y

: Variabel Terikat 


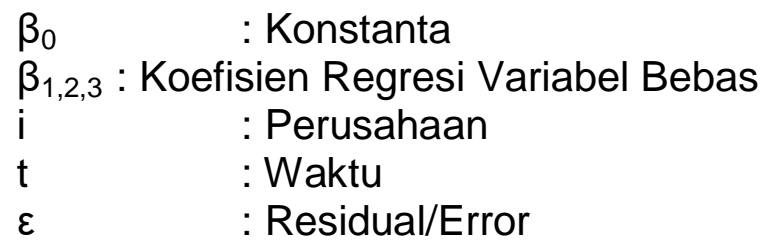

\section{HASIL}

Populasi penelitian ini adalah laporan keuangan perusahaan sektor agrikultur tahun 2016 sampai 2019 yang terdaftar di Bursa Efek Indonesia. Data yang digunakan dalam penelitian ini adalah data sekunder yang berasal dari laporan keuangan yang dipublikasi di website resmi Bursa Efek Indonesia yaitu www.idx.co.id. Berdasarkan kriteria pengambilan sampel yang telah ditetapkan, maka jumlah sampel dalam penelitian ini yaitu:

Tabel 1. Hasil Kriteria Sample Penelitian

\begin{tabular}{|c|c|c|}
\hline No & Keterangan & Jumlah \\
\hline 1. & $\begin{array}{l}\text { Jumlah perusahaan agriculture yang terdaftar di } \\
\text { BEl periode 2016-2019 }\end{array}$ & 24 \\
\hline 2. & $\begin{array}{l}\text { Perusahaan agrikultur yang tidak konsiten } \\
\text { publikasi laporan keuangan dan tahunannya di } \\
\text { Bursa Efek Indonesia. }\end{array}$ & (7) \\
\hline 3. & $\begin{array}{l}\text { Perusahaan agrikultur yang tidak menggunakan } \\
\text { mata uang Rupiah }\end{array}$ & (1) \\
\hline 4. & $\begin{array}{l}\text { Perusahaan agrikultur yang tidak mengalami } \\
\text { financial distress periode } 2016-2019 \text {. }\end{array}$ & (8) \\
\hline & Jumlah sampel penelitian $(8 \times 4)$ & 32 \\
\hline
\end{tabular}




\section{A. Analisis Statistik Deskriptif}

\begin{tabular}{|c|c|c|c|c|}
\hline View Proc Object & Print Name & Freeze] Sample & Sheet Stats & Spec \\
\hline & FINANCIALD... & ROE & CR & DAR \\
\hline & FINANCIALD... & ROE & CR & DAR \\
\hline Mean & 0.033249 & 0.093907 & 1.121609 & 0.638092 \\
\hline Median & 0.359672 & -0.021974 & 0.855972 & 0.635965 \\
\hline Maximum & 1.592171 & 5.173838 & 5.276987 & 1.648393 \\
\hline Minimum & -5.328095 & -1.352201 & 0.098608 & 0.084309 \\
\hline Std. Dev. & 1.378361 & 1.016425 & 1.182268 & 0.289539 \\
\hline Skewness & -2.034816 & 3.990096 & 2.213647 & 1.064106 \\
\hline Kurtosis & 8.253392 & 20.98342 & 7.507069 & 6.357422 \\
\hline Jarque-Bera & 58.88005 & 516.1158 & 53.21948 & 21.06876 \\
\hline Probability & 0.000000 & 0.000000 & 0.000000 & 0.000027 \\
\hline Sum & 1.063967 & 3.005015 & 35.89149 & 20.41893 \\
\hline Sum Sq. Dev. & 58.89623 & 32.02670 & 43.33048 & 2.598816 \\
\hline Observations & 32 & 32 & 32 & 32 \\
\hline
\end{tabular}

Gambar 1. Analisis Statistik Deskriptif

Nilai Mean terbesar dialami oleh variabel $C R$ yaitu sebesar 1,121609 sementara variabel Financial Distress memiliki nilai Mean terkecil yaitu sebesar 0,033249. Nilai Median terbesar dialami oleh variabel $C R$ yaitu sebesar 0,855972 sementara variabel ROE memiliki nilai Median terkecil yaitu sebesar -0,021974. Nilai Maximum terbesar dialami oleh variabel $C R$ yaitu sebesar 5,276987 sementara variabel Financial Distress memiliki nilai Maximum terkecil yaitu sebesar 1,592171. Nilai Minimum terbesar dialami oleh variabel $C R$ yaitu sebesar 0.098608 sementara variabel Financial Distress memiliki nilai Minimum terkecil yaitu sebesar -5,328095. Nilai Standar Deviasi terbesar dialami oleh variabel Financial Distress yaitu sebesar 1,378361 yang berarti bahwa variabel bahwa variabel Financial Distress memiliki tingkat risiko yang lebih tinggi mengalami perubahan dibandingkan dengan variabel-variabel yang lain selama periode penelitian. Sementara variabel $D A R$ mempunyai tingkat risiko yang paling rendah, yaitu sebesar 0,289539. Hal ini menunjukkan bahwa variabel $D A R$ selama periode penelitian mengalami perubahan yang tidak terlalu fluktuatif. Nilai Skewness yang memiliki nilai di atas 0 (nol) yaitu variabel $R O E, C R$ dan $D E R$ yang berarti bahwa asimetri distribusi data di sekitar mean tidak normal, sedangkan variabel Financial Distress memiliki nilai di sekitaran 0 (nol) yang berarti bahwa asimetri distribusi data di sekitar mean bersifat normal. Nilai Kurtosis untuk variabel Financial Distress, ROE, $C R$ dan DER memiliki nilai Kurtosis lebih dari 3 yang berarti bahwa ketinggian distribusi data tidak normal. Jarque-Bera adalah uji statistik untuk mengetahui apakah data berdistribusi normal. Uji ini mengukur perbedaan skewness dan kurtosis data dan dibandingkan dengan apabila datanya bersifat normal. Dengan $\mathrm{H}_{0}$ pada data berdistribusi normal, uji Jarque-Bera didistribusi dengan $\mathrm{X}^{2}$ dengan derajat bebas (degree of freedom) sebesar 2. Probability menunjukkan kemungkinan nilai Jarque-Bera melebihi (dalam nilai absolut) nilai terobservasi di bawah hipotesis nol. Nilai probabilitas yang kecil cenderung mengarahkan pada penolakan hipotesis nol distribusi normal. 
B. Estimasi Model Regresi Data Panel

1. Common Effect Model

Dependent Variable: FINANCIALDISTRESS

Method: Panel Least Squares

Date: $11 / 08 / 20$ Time: $18: 59$

Sample: 20162019

Periods included: 4

Cross-sections included: 8

Total panel (balanced) observations: 32

\begin{tabular}{lrlll}
\hline \hline \multicolumn{1}{c}{ Variable } & Coefficient & Std. Error & t-Statistic & Prob. \\
\hline \hline ROE & -0.131859 & 0.190187 & -0.693313 & 0.4936 \\
CR & 0.601139 & 0.137771 & 4.363331 & 0.0001 \\
DAR & -1.265223 & 0.326533 & -3.874720 & 0.0006 \\
\hline \hline R-squared & 0.465134 & Mean dependent var & 0.033249 \\
Adjusted R-squared & 0.428247 & S.D. dependent var & 1.378361 \\
S.E. of regression & 1.042238 & Akaike info criterion & 3.009678 \\
Sum squared resid & 31.50156 & Schwarz criterion & 3.147091 \\
Log likelihood & -45.15485 & Hannan-Quinn criter. & 3.055227 \\
Durbin-Watson stat & 0.675417 & & & \\
\hline \hline
\end{tabular}

\section{Gambar 2. Common Effect Model}

2. Fixed Effect Model

\begin{tabular}{|c|c|c|c|c|}
\hline \multicolumn{5}{|c|}{$\begin{array}{l}\text { Dependent Variable: FINANCIALDISTRESS } \\
\text { Method: Panel Least Squares } \\
\text { Date: } 11 / 08 / 20 \text { Time: } 19: 01 \\
\text { Sample: } 20162019 \\
\text { Periods included: } 4 \\
\text { Cross-sections included: } 8 \\
\text { Total panel (balanced) observations: } 32\end{array}$} \\
\hline Variable & Coefficient & Std. Error & t-Statistic & Prob. \\
\hline c & 2.213587 & 0.344700 & 6.421780 & 0.0000 \\
\hline ROE & 0.047855 & 0.095814 & 0.499452 & 0.6227 \\
\hline CR & 0.152744 & 0.106590 & 1.433010 & 0.1666 \\
\hline DAR & -3.692496 & 0.507363 & -7.277826 & 0.0000 \\
\hline \multicolumn{5}{|c|}{ Effects Specification } \\
\hline \multicolumn{5}{|c|}{ Cross-section fixed (dummy variables) } \\
\hline R-squared & 0.941188 & \multicolumn{2}{|c|}{ Mean dependent var } & 0.033249 \\
\hline Adjusted R-squared & 0.913182 & \multicolumn{2}{|c|}{ S.D. dependent var } & 1.378361 \\
\hline S.E. of regression & 0.406131 & \multicolumn{2}{|c|}{ Akaike info criterion } & 1.302007 \\
\hline Sum squared resid & 3.463798 & \multicolumn{2}{|c|}{ Schwarz criterion } & 1.805853 \\
\hline Log likelihood & -9.832107 & \multirow{2}{*}{\multicolumn{2}{|c|}{$\begin{array}{l}\text { Hannan-Quinn criter. } \\
\text { Durbin-Watson stat }\end{array}$}} & 1.469018 \\
\hline F-statistic & 33.60708 & & & 2.130456 \\
\hline Prob(F-statistic) & 0.000000 & \multicolumn{2}{|c|}{ Durbin-Watson stat } & \\
\hline
\end{tabular}

Gambar 3. Fixed Effect Model 
3. Random Effect Model

\begin{tabular}{|c|c|c|c|c|}
\hline \multicolumn{5}{|c|}{$\begin{array}{l}\text { Dependent Variable: FINANCIALDISTRESS } \\
\text { Method: Panel EGLS (Cross-section random effects) } \\
\text { Date: } 11 / 08 / 20 \text { Time: } 19: 03 \\
\text { Sample: } 20162019 \\
\text { Periods included: } 4 \\
\text { Cross-sections included: } 8 \\
\text { Total panel (balanced) observations: } 32 \\
\text { Swamy and Arora estimator of component variances }\end{array}$} \\
\hline Variable & Coefficient & Std. Error & t-Statistic & Prob. \\
\hline C & 2.173092 & 0.477225 & 4.553603 & 0.0001 \\
\hline ROE & 0.047346 & 0.093501 & 0.506375 & 0.6166 \\
\hline $\mathrm{CR}$ & 0.168263 & 0.102184 & 1.646663 & 0.1108 \\
\hline DAR & -3.656238 & 0.473746 & -7.717717 & 0.0000 \\
\hline \multicolumn{5}{|c|}{ Effects Specification } \\
\hline & & & S.D. & Rho \\
\hline Cross-section random & & & 0.978071 & 0.8529 \\
\hline Idiosyncratic random & & & 0.406131 & 0.1471 \\
\hline \multicolumn{5}{|c|}{ Weighted Statistics } \\
\hline R-squared & 0.712072 & \multirow{5}{*}{\multicolumn{2}{|c|}{$\begin{array}{l}\text { Mean dependent var } \\
\text { S.D. dependent var } \\
\text { Sum squared resid } \\
\text { Durbin-Watson stat }\end{array}$}} & 0.006759 \\
\hline Adjusted R-squared & 0.681222 & & & 0.692634 \\
\hline S.E. of regression & 0.391064 & & & 4.282069 \\
\hline F-statistic & 23.08215 & & & 1.735921 \\
\hline Prob(F-statistic) & 0.000000 & & & \\
\hline \multicolumn{5}{|c|}{ Unweighted Statistics } \\
\hline R-squared & 0.606839 & \multirow{2}{*}{\multicolumn{2}{|c|}{$\begin{array}{l}\text { Mean dependent var } \\
\text { Durbin-Watson stat }\end{array}$}} & 0.033249 \\
\hline Sum squared resid & 23.15569 & & & 0.321015 \\
\hline
\end{tabular}

Gambar 4. Random Effect Model

C. Teknik Pemilihan Model Regresi Data Panel

1. Uji Chow

\begin{tabular}{lcrr}
$\begin{array}{l}\text { Redundant Fixed Effects Tests } \\
\text { Equation: EQDARAJA } \\
\text { Test cross-section fixed effects }\end{array}$ & & & \\
\hline \hline Effects Test & Statistic & d.f. & Prob. \\
\hline \hline Cross-section F & 15.979964 & $(7,21)$ & 0.0000 \\
Cross-section Chi-square & 59.032692 & 7 & 0.0000 \\
\hline
\end{tabular}

Gambar 5. Uji Chow

Berdasarkan hasil diatas dapat dilihat bahwa nilai Probabilitas Cross-section $F$ dan Cross-section chi-square $0,0000<0,05$ maka dapat disimpulkan bahwa Fixed Effect Model (FEM) lebih layak digunakan dibandingkan Common Effect Model (CEM).

2. Uji Hausman

Correlated Random Effects - Hausman Test
Equation: EQDARAJA
Test cross-section random effects
\begin{tabular}{lrrr}
\hline Test Summary & Chi-Sq. Statistic & Chi-Sq. d.f. & Prob. \\
\hline \hline Cross-section random & 0.960940 & 3 & 0.8107 \\
\hline \hline & Gambar 6. Uji Hausman
\end{tabular}

Berdasarkan hasil diatas dapat dilihat bahwa nilai Probabilitas Crosssection random sebesar 0,8107 > 0,05 maka dapat disimpulkan bahwa Random Effect Model (REM) lebih layak digunakan dibandingkan FixedEffect Model (FEM). 
3. Uji Lagrange Multiplier

\begin{tabular}{|c|c|c|c|}
\hline & \multicolumn{3}{|c|}{ Test Hypothesis } \\
\hline & Cross-section & Time & Both \\
\hline Breusch-Pagan & $\begin{array}{l}11.47374 \\
(0.0007)\end{array}$ & $\begin{array}{l}0.059798 \\
(0.8068)\end{array}$ & $\begin{array}{l}11.53354 \\
(0.0007)\end{array}$ \\
\hline Honda & $\begin{array}{l}3.387291 \\
(0.0004)\end{array}$ & $\begin{array}{c}-0.244537 \\
-\end{array}$ & $\begin{array}{c}2.222263 \\
(0.0131)\end{array}$ \\
\hline King-Wu & $\begin{array}{l}3.387291 \\
(0.0004)\end{array}$ & $\begin{array}{c}-0.244537 \\
-\end{array}$ & $\begin{array}{l}1.650702 \\
(0.0494)\end{array}$ \\
\hline Standardized Honda & $\begin{array}{l}4.209413 \\
(0.0000)\end{array}$ & $\begin{array}{l}0.042520 \\
(0.4830)\end{array}$ & $\begin{array}{c}0.013530 \\
(0.4946)\end{array}$ \\
\hline Standardized King-Wu & $\begin{array}{l}4.209413 \\
(0.0000)\end{array}$ & $\begin{array}{l}0.042520 \\
(0.4830)\end{array}$ & $\begin{array}{c}-0.503659 \\
-\end{array}$ \\
\hline Gourierioux, et al.** & - & - & $\begin{array}{c}11.47374 \\
(<0.01)\end{array}$ \\
\hline
\end{tabular}

Gambar 7. Uji Lagrange Multiplier

Berdasarkan hasil diatas dapat dilihat bahwa nilai Probabilitas Cross-section Breusch-Pagan sebesar 0,0007 < 0,05 maka dapat disimpulkan bahwa Random Effect Model (REM) lebih layak digunakan dibandingkan Common Effect Model (CEM).

4. Kesimpulan Model

Berdasarkan hasil ke tiga pengujian yang sudah dilakukan maka dapat disimpulkan bahwa Model Regresi Data Panel yang akan digunakan dalam Uji Hipotesis dan Persamaan Regresi Data Panel adalah model Random Effect Model (REM), maka tidak perlu dilakukan uji asumsi klasik.

A. Uji Hipotesis

1. Uji Kelayakan Model (Uji F)

$\begin{array}{llll}\text { R-squared } & 0.712072 & \text { Mean dependent var } & 0.006759 \\ \text { Adjusted R-squared } & 0.681222 & \text { S.D. dependent var } & 0.692634 \\ \text { S.E. of regression } & 0.391064 & \text { Sum squared resid } & 4.282069 \\ \text { F-statistic } & 23.08215 & \text { Durbin-Watson stat } & 1.735921 \\ \text { Prob(F-statistic) } & 0.000000 & & \end{array}$

Gambar 8. Uji F

Pada hasil diatas menunjukkan bahwa nilai $F$-statistic sebesar 23,08215 sementara F-tabel dengan tingkat $\alpha=5 \%$, df1 $(k-1)=3$ dan df2 $(n-k)=28$ didapat $F$ tabel sebesar 2,95. Dengan demikian $F$ statistic $(23,08215)>\mathrm{F}$ Tabel $(2,95)$ dan nilai Prob (F-statistic) $0,000000<0,05$ maka dapat disimpulkan bahwa Ha diterima, dengan demikian dapat disimpulkan bahwa variabel-variabel bebas dalam penelitian yang terdiri dari $R O E, C R$ dan $D A R$ secara bersama-sama berpengaruh terhadap Financial Distress.

2. Koefisien Determinasi

$\begin{array}{llll}\text { R-squared } & 0.712072 & \text { Mean dependent var } & 0.006759 \\ \text { Adjusted R-squared } & 0.681222 & \text { S.D. dependent var } & 0.692634 \\ \text { S.E. of regression } & 0.391064 & \text { Sum squared resid } & 4.282069 \\ \text { F-statistic } & 23.08215 & \text { Durbin-Watson stat } & 1.735921 \\ \text { Prob(F-statistic) } & 0.000000 & & \end{array}$

Gambar 9. Koefisien Determinasi

Pada output diatas menunjukkan bahwa nilai Adjusted R-squared sebesar 0,681222, artinya bahwa variasi perubahan naik turunnya 
Financial Distress dapat dijelaskan oleh $R O E, C R$ dan DAR sebesar $68,12 \%$, sisanya $31,88 \%$ dijelaskan oleh variabel-variabel lain yang tidak diteliti dalam penelitian ini.

3. Uji t

\begin{tabular}{crrrr}
\hline \hline Variable & Coefficient & Std. Error & t-Statistic & Prob. \\
\hline \hline C & 2.173092 & 0.477225 & 4.553603 & 0.0001 \\
ROE & 0.047346 & 0.093501 & 0.506375 & 0.6166 \\
CR & 0.168263 & 0.102184 & 1.646663 & 0.1108 \\
DAR & -3.656238 & 0.473746 & -7.717717 & 0.0000 \\
\hline \hline
\end{tabular}

\section{Gambar 10. Uji t}

a. Nilai $t$-statistic $R O E 0,506375$, sementara t tabel tingkat $\alpha=5 \%$, $\mathrm{df}(\mathrm{n}-\mathrm{k})=28$ yaitu 2,048. Dengan demikian t-statistic $R O E$ $(0,506375)<t$ Tabel $(2,048)$ dan nilai Prob 0,6166 > 0,05. Disimpulkan ROE tidak berpengaruh terhadap Financial Distress.

b. Nilai $t$-statistic $C R$ 1.646663, sementara t tabel tingkat $\alpha=5 \%$, $\mathrm{df}(\mathrm{n}-\mathrm{k})=28$ yaitu 2,048. Dengan demikian t-statistic $C R$ $(1.646663)<\mathrm{t}$ Tabel $(2,048)$ dan nilai Prob 0,1108 > 0,05. Disimpulkan $C R$ tidak berpengaruh terhadap Financial Distress.

c. Nilai $t$-statistic $D A R-7.717717$, sementara t tabel tingkat $\alpha=5 \%$, $\mathrm{df}(\mathrm{n}-\mathrm{k})=28$ yaitu 2,048. dengan demikian t-statistic DAR (7.717717) < t Tabel $(2,048)$ dan nilai prob 0,0000 >0,05. Disimpulkan DAR berpengaruh negatif terhadap Financial Distress.

B. Persamaan Model Regresi Data Panel

Berdasarkan tabel Random Effect dapat diketahui bahwa persamaan regresi linier berganda adalah sebagai berikut: Makna:

$Y=2,173092+0,047346+0,168263-3,656238+\varepsilon$

1. Nilai konstanta sebesar 2,173092 menunjukkan bahwa jika variabel bebas tidak ada atau bernilai 0 maka nilai financial distress sebesar 2,173092.

2. Nilai koefisien regresi variabel $R O E$ positif sebesar 0,047346 . Hal ini berarti semakin besar ROE, maka pengungkapan financial distress semakin tinggi.

3. Nilai koefisien regresi variabel $C R$ positif sebesar 0,168263 . Hal ini berarti semakin besar $C R$, maka pengungkapan financial distress semakin tinggi.

4. Nilai koefisien regresi $D A R$ negatif sebesar $-3,656238$. Hal ini berarti semakin besar $D A R$, maka pengungkapan financial distress semakin rendah.

C. Intrepretasi Hasil

1. Return on Equity menunjukkan koefisien positif sebesar 0,506375 dengan tingkat signifikansi sebesar 0,6166 $>\alpha=0.05$. Karena tingkat signifikan lebih besar dari $\alpha=0.05$ maka $\mathrm{H} 1$ ditolak sehingga simpulannya adalah ROE tidak berpengaruh terhadap Financial Distress. Hasil penelitian ini didukung oleh penelitian 
yang dilakukan Rina Erayanti (2019) Hasil pengujian hipotesis atas pengaruh variabel profitabilitas (Return On Equity) terhadap financial distress menunjukkan bahwa tidak adanya pengaruh variabel profitabilitas secara signifikan terhadap financial distress.

2. Current Ratio menunjukkan koefisien positif sebesar 1.646663 dengan tingkat signifikansi sebesar $0,1108>\alpha=0.05$. Karena tingkat signifikan lebih besar dari $\alpha=0.05$ maka $\mathrm{H} 2$ ditolak sehingga simpulannya adalah $C R$ tidak berpengaruh terhadap financial distress. Hasil penelitian ini didukung oleh penelitian yang dilakukan Srikalimah, SE.,MM (2017) Likuiditas (CR) tidak mempunyai pengaruh yang signifikan dalam memprediksi financial distress.

3. Debt to Asset Ratio menunjukkan koefisien negatif sebesar 7.717717 dengan tingkat signifikansi sebesar $0,0000<\alpha=0.05$. Karena tingkat signifikan lebih kecil dari $\alpha=0.05$ maka $\mathrm{H} 3$ diterima sehingga simpulannya adalah $D A R$ berpengaruh terhadap financial distress. Hasil penelitian ini didukung oleh penelitian yang dilakukan Lysy Claudia Moleong (2018) Variabel tingkat leverage $(D A R)$ berpengaruh terhadap financial distress.

\section{KESIMPULAN}

Berdasrkan hasil penelitian, maka dapat disimpulkan sebagai berikut:

1. Secara simultan (Uji F) variabel ROE, CR dan DAR secara bersamasama memiliki pengaruh terhadap Financial Distress.

2. Secara parsial (Uji t):

a. ROE tidak memiliki pengaruh yang signifikan dalam memprediksi Financial Distress.

b. CR tidak memiliki pengaruh yang signifikan dalam memprediksi Financial Distress.

c. DAR yang hanya memiliki pengaruh negatif signifikan dalam memprediksi Financial Distress perusahaan sektor agrikultur yang terdaftar di BEl periode 2016-2019.

\section{DAFTAR PUSTAKA}

Adharsyah, T. (2019, May). Pertumbuhan Ekonomi Loyo Gara-gara Pertanian Pangan Negatif. CNBC Indonesia. Jakarta. Retrieved from https://www.cnbcindonesia.com/market/20190506122658-1770692/pertumbuhan-ekonomi-loyo-gara-gara-pertanian-pangannegatif. $\leftarrow$ ARTIKEL KORAN

Bursa Efek Indonesia, Laporan Keuangan Tahunan 2016, 2017, 2018, 2019 http://www.idx.co.id. $\leftarrow$ WEBSITE

Curry, K., Banjarnahor, E., Diploma, P., \& Keuangan, E. (2018). Financial Distress Pada Perusahaan Sektor Properti Go, 207-221. $\leftarrow$ JURNAL ILMIAH

Eksandy, A. (2018). Metode Penelitian Akuntansi dan Manajemen. (M. Z. Hakim, Ed.). Tangerang: FEB UMT. $\leftarrow$ BUKU 
Erayanti, R. (2019). Pengaruh Likuiditas, Profitabilitas dan Leverage terhadap Prediksi Financial Distress. Jurnal Riset Akuntansi \& Perpajakan (JRAP), 6(01), 38-51. $\leftarrow$ JURNAL ILMIAH

Ginting, M. (2017). Pengaruh Current Ratio dan Debt To Equity Ratio (DER) terhadap Financial Distress pada Perusahaan Property \& Real Estate di Bursa Efek Indonesia. Jurnal Manajemen, 3(2), 3744. $\leftarrow$ JURNAL ILMIAH

Moleong, L. C. (2018). Pengaruh Real Interest Rate dan Leverage Terhadap Financial Distress. Modus, 30(1), 71-86. $\leftarrow$ JURNAL ILMIAH

Srikalimah. (2017). JURNAL AKUNTANSI \& EKONOMI FE. UN PGRI Kediri Vol. 2 No. 1, Maret 2017. Jurnal Akuntansi \& Ekonomi FE. UN PGRI Kediri, 2(1), 43-66. $\leftarrow$ JURNAL ILMIAH

Sugiyono. (2011). Metode Penelitian Kuantitatif Kualitatif dan R\&D. Bandung: CV Alfabeta. $\leftarrow$ BUKU

Syaputri, N. (2019). Pengaruh Profitabilitas, Likuiditas, dan Ukuran Perusahaan Terhadap Penghindaran Pajak Pada Perusahaan Manufaktur Subsektor Makanan dan Minuman Yang Terdaftar Di BEI Periode 2013-2017. Universitas Muhammadiyah Sumatera Utara. $\leftarrow$ JURNAL ILMIAH

Widarjono, A. (2007). Ekonometrika: Teori dan Aplikasi Untuk Ekonomi dan Bisnis (edisi kedu.). Yogyakarta: Ekonisia FE Universitas Islam Indonesia. $\leftarrow$ BUKU

Wijarnarto, H., \& Nurhidayat, A. (2016). PENGARUH RASIO KEUANGAN DALAM MEMPREDIKSI FINANCIAL DISTRESS PADA PERUSAHAAN DI SEKTOR PERTANIAN DAN PERTAMBANGAN YANG TERDAFTAR DI BURSA EFEK INDONESIA. PENGARUH RASIO KEUANGAN DALAM MEMPREDIKSI FINANCIAL DISTRESS PADA PERUSAHAAN DI SEKTOR PERTANIAN DAN PERTAMBANGAN YANG TERDAFTAR DI BURSA EFEK INDONESIA, VOI.2 NO.O. $\leftarrow$ JURNAL ILMIAH 